\title{
Immunohistochemical detection of ER $\beta$ in breast cancer: towards more detailed receptor profiling?
}

\author{
GP Skliris', PJ Carder², MRJ Lansdown ${ }^{3}$ and V Speirs ${ }^{1}$ \\ 'Molecular Medicine Unit, University of Leeds, Clinical Sciences Building, St James's University Hospital, Leeds LS9 7TF; ${ }^{2}$ Pathology Department and \\ ${ }^{3}$ Breast Unit, St. James's University Hospital, Leeds, LS9 7TF
}

Summary Oestrogen receptor (ER) is used routinely to predict endocrine responsiveness in patients with breast cancer. A second ER, ER $\beta$ has been described but its significance remains undefined; most studies have described mRNA levels rather than protein expression. Here, we demonstrate for the first time, immunohistochemical detection of ER $\beta$ in archival breast tumours. (C) 2001 Cancer Research Campaign http://www.bjcancer.com

Keywords: ER $\beta$; breast cancer; immunohistochemistry; formalin-fixed; paraffin-embedded material

2 human ER isoforms exist, the 'classic' ER $\alpha$ (Green et al, 1986) and the more recently identified ER $\beta$ (Kuiper et al, 1996; Mosselman et al, 1997). Immunohistochemical analysis of ER $\alpha$ in breast cancer is now routine practice and plays a major role in the selection of adjuvant therapy in patients with this disease (Harvey et al, 1999). Pilot work at the mRNA level suggests a role for ER $\beta$ in tamoxifen resistance (Speirs et al, 1999a). However, few studies have investigated protein expression in archival material. This is fundamental because there is no guarantee that mRNA will be translated into functional protein. Recently, immunohistochemical detection of ER $\beta$ was reported in frozen sections of normal (Speirs et al, 2000) and malignant breast (Jarvinen et al, 2000). However, for $\operatorname{ER} \beta$ to be of clinical use it is essential to identify a suitable antibody for its detection in formalin-fixed, paraffin-embedded tumours, since the majority of clinical samples are processed in this way. Therefore, we have optimized an antigen retrieval histochemical technique using a suitable antibody, capable of detecting ER $\beta$ protein in archival human breast carcinomas.

\section{MATERIALS AND METHODS}

With ethical approval, 65 breast carcinomas (35 infiltrating ductal, 15 lobular, 9 tubular/cribriform, 4 mucinous, 1 DCIS, 1 medullary) and 8 normal breast tissues were randomly selected. None of the patients had been treated pre-operatively with endocrine therapy. Detection of ER $\beta$ by immunohistochemistry (IHC) was performed using a monoclonal antibody (ER $\beta-14 \mathrm{C} 8$, Abcam, Cambridge, UK). The antibody was affinity-purified and raised by immunizing mice with a recombinant protein encoding 1-153 amino acids of human ER $\beta$ sequence. According to the manufacturers $14 \mathrm{C} 8$ did not cross react with $\mathrm{hER} \alpha$. This was further confirmed by incubating $14 \mathrm{C} 8$ and anti-ER $\alpha$ (1D5, Dako, UK) with an ER $\beta$ blocking peptide (sc-6820P; Autogen Bioclear, UK). Appropriate positive controls (normal human breast) and negative (omission of primary antibody, incubation with blocking peptide) were also included.

Received 30 November 2000

Revised 24 January 2001

Accepted 24 January 2001

Correspondence to: $\mathrm{V}$ Speirs
$5 \mu \mathrm{m}$ sections were mounted on Superfrost slides (BDH, Poole, UK), microwaved in $0.01 \mathrm{M}$ citrate buffer, $\mathrm{pH} 6.0$, for $27 \mathrm{~min}$ at $480 \mathrm{~W}$ then incubated overnight with $5 \mu \mathrm{g} \mathrm{ml}^{-1}$ primary antibody at $4^{\circ} \mathrm{C}$. Next, sections were incubated with biotinylated secondary antibody followed by streptavidin/peroxidase complex (Vectastain Quick Kit) at room temperature and visualized with 3,3'-diaminobenzidine (all Vector, Peterborough, UK). Sections were counterstained with haematoxylin, dehydrated and coverslipped. Slides were observed under a Nikon light microscope and images captured using Lucia software (version 4.51). A simple scoring system was used involving assessment of both staining intensity and percentage positivity, generating a numerical score of $0-8$. A score of $>2$ was classified as positive (Allred et al, 1998). Staining was scored independently by two authors (GPS, PJC). Statistical analysis was performed using Fisher's exact test.

\section{RESULTS}

Consistent, strong ER $\beta$ staining was detected specifically in cell nuclei of both epithelial and myoepithelial cells from normal breast ducts and lobules, both in breast reduction specimens and normal tissue adjacent to tumours (Figure 1A, B). $74 \%$ of carcinomas (48/65) exhibited specific nuclear staining for ER $\beta$ (Figure 1C,D,E). Light cytoplasmic staining was visualized in some tumours, scored as ER $\beta$ negative if seen alone, whilst occasional weak to moderate staining was seen in surrounding stromal cells. Specific staining was abolished where primary antibody was substituted with blocking serum or pre-absorbed with an ER $\beta$ blocking peptide (Figure 1F). No effect of this peptide was seen with primary antibody directed against ER $\alpha$ (data not shown). Results obtained between different test runs were consistently reproducible.

Compared with infiltrating ductal carcinomas, invasive lobular, tubular/cribriform and mucinous tumours showed significantly increased $\mathrm{ER} \beta$ positivity $(P=0.02$, Table 1$)$, illustrating the differences in biological characteristics between distinct tumour types. However, when the results were correlated with clinicopathological features, ER $\beta$ was significantly associated with $\mathrm{ER} \alpha$, PR and well-differentiated tumours (Table 1). 

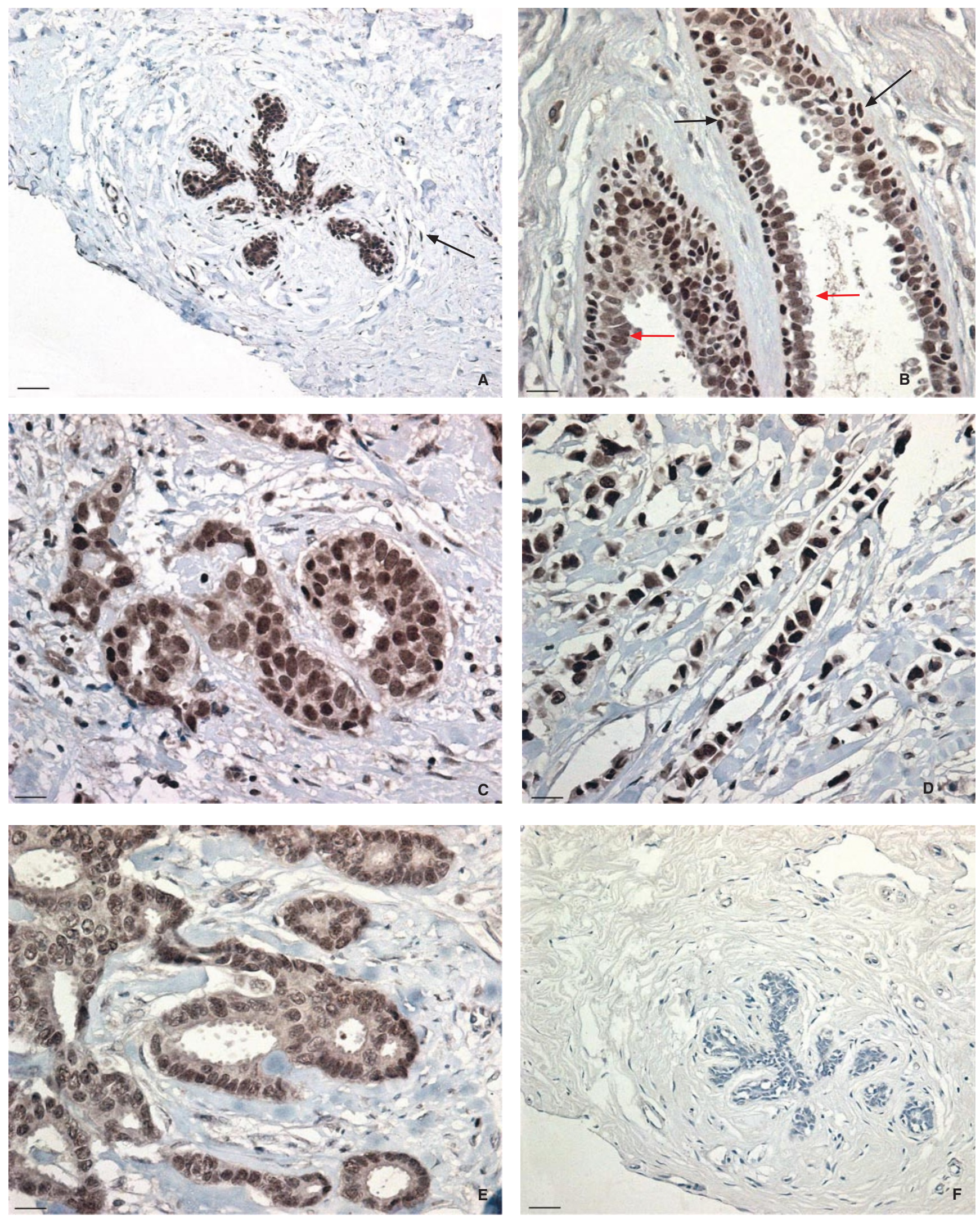

Figure 1 (A) Immunohistochemical detection of ER $\beta$ protein in cell nuclei of breast ducts. Note occasional positivity in stromal cells (arrow). (B) ER $\beta$ expression in the nuclei of both epithelial (red arrows) and myoepithelial cells (black arrows) of normal mammary glands. (C) Invasive ductal carcinoma showing specific nuclear staining for ER $\beta$. (D) Strong ER $\beta$ immunoreactivity localized in cell nuclei of an invasive lobular carcinoma. (E) Invasive tubular/cribriform tumour expressing ER $\beta$ protein. $(\mathbf{F})$ Serial section of $(\mathbf{A})$ showing abolition of specific staining following pre-absorption of primary antibody with an ER $\beta$ blocking peptide. Bars $=1 \mu \mathrm{m}$ 
Table 1 Association of ER $\beta$ with clinico-pathological features in 65 breast carcinomas

\begin{tabular}{|c|c|c|c|}
\hline Parameter & $E R \beta+$ & $E R \beta-$ & $P$ value \\
\hline \multicolumn{4}{|l|}{ Receptors ${ }^{a}$} \\
\hline $\mathrm{ER} \alpha+$ & 40 & 10 & 0.03 \\
\hline $\mathrm{ER} \alpha-$ & 6 & 7 & \\
\hline PR+ & 31 & 6 & 0.002 \\
\hline PR- & 8 & 11 & \\
\hline $\mathrm{ER} \alpha+/ \mathrm{PR}+$ & 32 & 5 & $\mathrm{ER} \alpha+/ \mathrm{PR}+$ vs. $\mathrm{ER} \alpha+/ \mathrm{PR}-=0.024$ \\
\hline $\mathrm{ER} \alpha+/ \mathrm{PR}-$ & 3 & 4 & \\
\hline $\mathrm{ER} \alpha--/ \mathrm{PR}+$ & 0 & 0 & \\
\hline $\mathrm{ER} \alpha-/ \mathrm{PR}-$ & 5 & 7 & $\mathrm{ER} \alpha+/ \mathrm{PR}+$ vs. $\mathrm{ER} \alpha-/ \mathrm{PR}-=0.004$ \\
\hline \multicolumn{4}{|l|}{ Lymph node ${ }^{a}$} \\
\hline+ & 15 & 5 & 0.77 \\
\hline- & 29 & 13 & \\
\hline \multicolumn{4}{|l|}{ Menopause } \\
\hline Post- & 44 & 13 & 0.19 \\
\hline Pre- & 4 & 4 & \\
\hline \multicolumn{4}{|l|}{ Tumour type ${ }^{b}$} \\
\hline Ductal & 22 & 13 & Ductal vs. lobular $=0.18$ \\
\hline Lobular & 13 & 2 & Ductal vs. all other types $=0.02$ \\
\hline Tubular/cribriform & 8 & 1 & Ductal vs. tubular/cribriform $=0.23$ \\
\hline Mucinous & 4 & 0 & \\
\hline \multicolumn{4}{|l|}{ Tumour size } \\
\hline$\leq 2 \mathrm{~cm}$ & 31 & 12 & 0.77 \\
\hline$>2 \mathrm{~cm}$ & 17 & 5 & \\
\hline \multicolumn{4}{|l|}{ Histological grade } \\
\hline 1 & 15 & 3 & I vs. ||$=1.0$ \\
\hline II & 24 & 4 & I vs. III = 0.04 \\
\hline III & 9 & 10 & II vs. III = 0.009 \\
\hline
\end{tabular}

aUnknown $\mathrm{ER} \alpha$ status $=2$, unknown $\mathrm{PR}$ status $=9$, unknown node status $=3$. ${ }^{\text {bExcludes one }}$ medullary carcinoma and one DCIS.

\section{DISCUSSION}

Our results unequivocally demonstrate that $\operatorname{ER} \beta$ can be routinely detected, in archival, formalin-fixed, paraffin-embedded breast tumours using the $14 \mathrm{C} 8$ monoclonal antibody. This may have profound clinical implications, as it will now allow detailed receptor analysis in the routine diagnostic setting.

ER $\beta$ was co-expressed with ER $\alpha$ in $74 \%$ of tumours and showed a strong association with PR and well-differentiated tumours. This is in concordance with Jarvinen (2000), but refutes the observations of Dotzlaw et al (1999). However, the latter study was conducted at the mRNA level, highlighting that caution should be observed when extrapolating mRNA results to those of protein.

Many ER $\beta$ antibodies have become commercially available over the last year. Despite this, there is a paucity of studies investigating this protein in breast tumours. Taylor and Al-Azzawi (2000) reported ER $\beta$ in a range of formalin-fixed normal human material, including breast. They used 2 polyclonal antibodies raised against the N- and C-termini of hER $\beta$ (06-629, Upstate Biotechnology; PAI-310, Affinity Bioreagents, USA respectively). In addition, Jarvinen et al (2000) reported successful detection of ER $\beta$ in frozen tumours, using a different polyclonal antibody (PAI-313, Affinity Bioreagents, USA), but interestingly their attempts with paraffin material were unsuccessful. Frozen sections are performed infrequently in routine practice, so there is a need for a suitable antibody and a reliable technique for use in paraffin sections. To our knowledge, this is one of the first studies reporting ER $\beta$ in paraffin-embedded human breast carcinomas. The availability of $14 \mathrm{C} 8$ should help resolve conflicting reports proposing
ER $\beta$ as a good (Jarvinen et al, 2000) or poor (Dotzlaw et al, 1999; Speirs et al, 1999a,b) prognostic factor in breast cancer.

Presence of ER $\beta$ in breast tumours may help explain the differential tissue- or gene-specific effects, which have been reported with oestrogens/antioestrogens (Paech et al, 1997). The relative expression of ER subtypes seems to alter during tumorigenesis in terms of mRNA (Leygue et al, 1998); if this is borne out at protein level, it could have relevance with respect to novel selective ER modulators, currently being developed against specific ER phenotypes. When these become available, they could offer the possibility of individually tailored therapy based on the particular receptor profiles of breast carcinomas.

\section{ACKNOWLEDGEMENTS}

We thank Yorkshire Cancer Research and Northern and Yorkshire NHS Executive for financial support. Thanks to Jane Ramsdale for technical assistance.

\section{REFERENCES}

Allred DC, Harvey MJ, Berardo M and Clark GM (1998) Prognostic and predictive factors in breast cancer by immunohistochemical analysis. Mod Pathol 2 : $155-168$

Dotzlaw H, Leygue E, Watson PH and Murphy LC (1999) Estrogen receptor $\beta$ messenger RNA expression in human breast tumour biopsies: Relationship to steroid receptor status and regulation by progestins. Cancer Res 59: 529-532

Green S, Walter P, Kumar V, Krust A, Bornert JM, Argos P and Chambon P (1986) Human oestrogen receptor cDNA: sequence, expression and homology to v-erb-A. Nature 320: 134-139 
Harvey JM, Clark GM, Osborne CK and Allred DC (1999) Estrogen receptor status by immunohistochemistry is superior to the ligand-binding assay for predicting response to adjuvant endocrine therapy in breast cancer. J Clin Oncol 17: $1474-1481$

Jarvinen TAH, Pelto-Huikko M, Holli K and Isola J (2000) Estrogen receptor $\beta$ is co-expressed with ER $\alpha$ and PR and associated with nodal status, grade and proliferation in breast cancer. Am J Pathol 156: 29-35

Kuiper GG, Enmark E, Pelto-Huikko M, Nilsson S and Gustaffson JA (1996) Cloning of a novel receptor expressed in rat prostate and ovary. Proc Natl Acad Sci USA 93: 5925-5930

Leygue E, Dotslaw H, Watson PH and Murphy LC (1998) Altered estrogen receptor $\alpha$ and $\beta$ messenger RNA expression during human breast tumorigenesis. Cancer Res 58: 3197-3201

Mosselman S, Polman J and Dijkema R (1996) ER- $\beta$ : identification and characterisation of a novel human estrogen receptor. FEBS Lett 392 : $49-53$
Paech K, Webb P, Kuiper GGJM, Nilsson S, Gustaffson J-A, Kushner PJ and Scanlan TS (1997) Differential ligand activation of estrogen receptors ER $\alpha$ and ER $\beta$ at AP-1 sites. Science 277: 1508-1510

Speirs V, Malone C, Walton DS, Kerin MJ and Atkin SL (1999a) Increased expression of estrogen receptor $\beta$ mRNA in tamoxifen-resistant breast cancer patients. Cancer Res 59: 5421-5424

Speirs V, Parkes AT, Kerin MJ, Walton DS, Carleton PJ, Fox JN and Atkin SL (1999b) Co-expression of estrogen receptor- $\alpha$ and $-\beta$ : Poor prognostic factors in human breast cancer? Cancer Res 59: 525-528

Speirs V, Adams IP, Walton DS and Atkin SL (2000) Identification of wild type and exon 5 deletion variants of estrogen receptor $\beta$ in normal human mammary gland. J Clin Endo Metab 85: 1601-1605

Taylor AH and Al-Azzawi F (2000) Immunolocalisation of oestrogen receptor beta in human tissues. J Molec Endocrinol 24: 145-155 